\title{
EDIBLE PORTION KARKAS, KADAR LEMAK DAN KOLESTEROL DAGING DOMBA DENGAN IMBANGAN AMPAS BIR DAN RUMPUT GAJAH YANG BERBEDA
}

\author{
Agus Priyono dan Imbang Haryoko \\ Fakultas Peternakan UNSOED
}

\begin{abstract}
ABSTRAK
Penelitian bertujuan untuk mengevaluasi kandungan edible portion karkas domba serta upaya untuk menghasilkan daging domba yang berkualitas (rendah kandungan asam-asam lemak jenuh dan kolesterol). Penelitian menggunakan domba lokal jantan sebanyak 16 ekor, umur 4 (empat) bulan dengan bobot badan (BB) 5-10 kg. Bahan pakan yang digunakan adalah : konsetrat, rumput gajah, dedak, ampas bir, garam dan mineral mix. Penelitian dilaksanakan dengan metode eksperimental secara in vivo selama 150 hari. Rancangan yang digunakan Rancangan Acak Kelompok (RAK) dengan empat macam perlakuan. Masingmasing perlakuan dilakukan pengulangan sebanyak empat kali. Ransum perlakuan yaitu imbangan ampas bir dengan rumput gajah yang diberikan adalah sebagai berikut : R1 = 12\% ampas bir : $48 \%$ rumput gajah; R2 = $24 \%$ ampas bir : $36 \%$ rumput gajah; $\mathrm{R}_{3}=36 \%$ ampas Bir : $24 \%$ rumput gajah; dan $\mathrm{R} 4=48 \%$ ampas bir : $12 \%$ rumput gajah. Variabel yang diukur adalah : edible portion karkas (\%) (bobot karkas, edible meat atas, dan edible meat bawah); kadar lemak daging, kadar kolesterol daging dan hati domba. Hasil penelitian menunjukkan bahwa perlakuan berpengaruh nyata $(\mathrm{P}<0.05)$ terhadap persentase edible meat bawah, tetapi tidak berpengaruh nyata terhadap kadar lemak dan kolesterol daging domba. Kesimpulan hasil penelitian bahwa imbangan $48 \%$ ampas bir : $12 \%$ rumput gajah dapat digunakan sebagai campuran pakan domba tanpa mengganggu aktivitas fisiologi dan metabolisme domba.
\end{abstract}

Kata kunci : ampas bir, edible portion meat, kolesterol

\begin{abstract}
ABSTRACK
The research was aimed to evaluated edible portion meat and as an effort to improve the quality of lamb meat. (low content of saturated fatty acids and cholesterol), with brewery waste. The research used 16 four months old local rams with body weight 5-10 kgs. The feed composition used was Pennisetum purpureum grass, rice bran, beer solid waste, salt and minerals mix. The research used experimental method in vivo for 150 days using Completely Randomized Design with four treatments. Each treatment was with four repetition. Treatment rations were R $1=12 \%$ brewery waste: $48 \%$ grass; R2 $=24 \%$ brewery waste: $36 \%$ grass; $\mathrm{R}_{3}=36 \%$ brewery waste: $24 \%$ grass; R4= $48 \%$ brewery waste: $12 \%$ grass. The variables measured were : edible portion of carcass (\%) (carcass weight, edible meat proximal and edible meat distal); the fat content of meat, meat and liver cholesterol of lamb meat. The results showed that the treatment significantly affect $(\mathrm{P}<0.05)$ to the percentage of edible meat distal, but not significantly terhadapa levels of fat and cholesterol lamb. Conclusion of the research that the balance $48 \%$ brewery waste: $12 \%$ of elephant grass can be used as a mixture of lamb feed without disrupting the activity of the physiology and metabolism of lamb
\end{abstract}

Keywords : solid waste of beer, edible portion meat, cholesterol

\section{PENDAHULUAN}

Potensi untuk mengembangkan ternak domba sangat terbuka lebar, karena 30\% kebutuhan pangan dipenuhi oleh ternak. Konsumsi daging domba di Indonesia baru mencapai $0,24 \mathrm{~g}$, sedangkan konsumsi di Negara maju 3,33 g di Jerman, dan 81,11 g di New Zaeland, hal ini menunjukkan bahwa masih terbuka luas untuk pengembanga ternak domba.

Rendahnya konsumsi daging domba di Indonesia, dipengaruhi juga oleh pandangan konsumen bahwa kandungan asam-asam lemak jenuh pada daging domba dapat menyebabkan gangguan kesehatan seperti kolesterol, artherioskeloris, dan jantung koroner. Kandungan asam lemak jenuh pada daging domba disebabkan karena adanya proses biohidrogenasi asam lemak tidak jenuh menjadi asam lemak jenuh dalam rumen. Reaksi ini dapat dihambat menggunakan tannin. Tannin akan masuk dan menempati pusat enzim pada otot, karena tannin mampu melewati saluran pencernaan tanpa diabsopsi dan tidak menetap di vena porta. Tannin 
dapat meningkatkan pertambahan bobot badan, pertumbuhan bulu, produksi susu dan performan reproduksi, mempengaruhi kualitas karkas, bobot karkas, serta lemak karkas ( Priolo et al.,1998).

\section{METODE PENELITIAN}

Penelitian ini menggunakan domba lokal jantan sebanyak 16 ekor, umur 4 (empat) bulan dengan bobot badan (BB) 5-10 kg. Bahan pakan yang digunakan adalah : HIjauan 60\% terdiri dari rumput gajah dan ampas bir. Konsentrat 40\% yang terdiri dari : onggok $25 \%$, dedak $73 \%$, garam $1 \%$, dan mineral mix $1 \%$. Penelitian dilaksanakan dengan metode eksperimental secara in vivo selama 150 hari. Metode eksperimen menggunakan Rancangan Acak Kelompok (RAK) dengan empat macam perlakuan. Masing-masing perlakuan dilakukan pengulangan sebanyak empat kali. Ransum perlakuan yang diberikan adalah sebagai berikut : $\mathrm{R}_{1}=12 \%$ Ampas Bir: 48\% Rumput gajah; $\mathrm{R}_{2}=24 \%$ Ampas Bir : $36 \%$ Rumput gajah; $\mathrm{R}_{3}=36 \%$ Ampas Bir :24 \% Rumput gajah; $\mathrm{R}_{4}=48$ \% Ampas Bir : 12 \% Rumput gajah. Peubah respon : Bobot karkas, Edible Meat Atas, Edible Meat Bawah, Kadar Lemak Daging (AOAC, 1995) dan Kadar Kolesterol Daging (Penentuan Kadar Kolesterol Daging Metode Lieberman Dan Burchad Menggunakan Spektrofotometer. (Tranggono dan setiaji, 1989).

\section{HASIL DAN PEMBAHASAN}

Hasil penelitian imbangan ampas bir dengan rumput gajah yang berbeda disajikan pada Tabel 1 . Tabel 1 menunjukkan bahwa perlakuan berpengaruh tidak nyata $(\mathrm{P}>0,05)$ terhadap bobot karkas, edible meat atas. Bobot karkas yang diperoleh hasil penelitian berkisar 45,36 $\left(\mathrm{R}_{1}\right)$ sampai $45,75 \%\left(\mathrm{R}_{4}\right)$, hasil ini sejalan dengan hasil penelitian Yosep, (2007) bahwa karkas domba yang diperoleh hasil penelitian berkisar 40,82-56,93\%. Rahmadi (2003) domba lokal jantan yang diberi pakan komplit, selama 9 minggu diperoleh bobot karkas sebesar 49,68\%. Perlakuan jenis pakan komplit tidak menyebabkan perbedaan ( $\mathrm{P}>0,05)$ terhadap bobot daging, lemak, dan edible portion karkas domba. edible portion karkas sebesar 73,83\% dari bobot karkas (Arifin et al., 2009).

Perlakuan berpengaruh nyata $(\mathrm{P}<0,05)$ terhadap persentase edible meat bawah Perlakuan R1 nyata menghasilkan edible meat bawah lebih besar dibandingkan dengan perlakuan yang lain. Hal ini menunjukkan bahwa penggunaan ampas bir $12 \%$, 48\% Rumput gajah dan 40\% Konsentrat dapat digunakan untuk meningkatkan bobot edible meat. Hasil penelitian Arifin dkk. (2009), bahwa persentase edible portion karkas hasil penelitian sebesar 73,83\%
Tabel 1. Rataan Hasil Penelitian

\begin{tabular}{|c|c|c|c|c|}
\hline & $\mathrm{R}_{1}$ & $\mathrm{R}_{2}$ & R3 & R4 \\
\hline Bobot Karkas (\%) ${ }^{\text {ns }}$ & 45,36 & 45,40 & 41,46 & 45,75 \\
\hline Edible meat atas (\%) ${ }^{\mathrm{ns}}$ & 30,15 & 31,98 & 31,50 & 29,48 \\
\hline Edible meat bawah (\%) & 24,36 & 31,56 & 29,28 & 25,26 \\
\hline Kadar lemak daging (\%) & 9,535 & 9,511 & 8,093 & 8,976 \\
\hline $\begin{array}{l}\text { Kadar Kolesterol Daging } \\
(\mathrm{mg} / \mathrm{g})\end{array}$ & 165,45 & 177,05 & 191,27 & 158,96 \\
\hline $\begin{array}{l}\text { Kolesterol hati domba } \\
\text { (mg/g) }\end{array}$ & 235 & 274 & 245 & 237 \\
\hline
\end{tabular}

dari bobot karkas. Persentase edible portion karkas hasil penelitian ini lebih rendah dibandingkan hasil penelitian Lestari et al. (2001), yaitu 75,64-78,96\% atau hasil penelitian Ferrier et al. (1995), yaitu sebesar $89 \%$.

Cividini et al. (2007) menemukan perbedaan karakeristik karkas domba yang disebabkan oleh sistem produksi, domba yang dipelihara pada padang gembala menghasilkan karkas dengan lemak yang lebih sedikit daripada dipelihara secara feedlot dengan pakan hijauan dan konsentrat. Perlakuan berpengaruh tidak nyata $(\mathrm{P}>0,05)$ terhadap kadar lemak dan kadar kolesterol daging serta kadar kolesterol hati (Tabel 2). Hal ini menunjukkan bahwa domba yang diberi ampas bir sebagai campuran pakan domba belum mampu untuk menghambat proses biohidrogenasi dalam rumen disebabkan karena tannin yang terkandung dalam pakan sebesar $20 \mathrm{~g} / \mathrm{kg} \mathrm{BK}$, sedangkan untuk menghambat proses biohidrogenasi dalam rumen dibutuhkan tannin sebesar $200 \mathrm{~g} / \mathrm{Kg}$ BK. Tanin dalam rumen dapat digunakan untuk menghambat proses pembentukan lemak maupun kolesterol. Purchas and Keogh (1984) menyatakan bahwa proses lipogenesis akan menurunkan kandungan lemak karkas domba yang diberi pakan hijauan mengandung tannin.

\section{KESIMPULAN}

Hasil penelitian bahwa imbangan $48 \%$ ampas bir : $12 \%$ rumput gajah dapat digunakan sebagai campuran pakan domba tanpa mengganggu aktivitas fisiologi dan metabolisme domba, dan pada imbangan $12 \%$ Ampas Bir: 48 \% Rumput gajah serta 40 \% Konsentrat dapat digunakan untuk meningkatkan bobot edible meat.

\section{DAFTAR PUSTAKA}

AOAC. 1995. Official Method of Analysis. 13th ed. Association of Official Analytical Chemistry, Washington DC.

Arifin,M., A. M. Hasibuan, C. M. S. Lestari, E. Purbowati, C.I. Sutrisno, E. Baliarti, S.P.S. Budhi dan W. Lestariana. 2009. Produksi Edible Portion Karkas Domba Ekor Tipis Jantan Yang Diberi 
Pakan Komplit Dengan Bahan Baku Berbagai Limbah Pertanian. ([Edible Carcass Production of Thin Tail Lambs Fed Complete Feed Composed of Various Agricultural By- products). J.Indon. Trop.Anim.Agric. 34 [2] June 2009

Barry, T.N., Manley, T.R. and Duncan, S.J. 1986. The role of condensed tannins in the nutritional value of Lotus pedunculatus for sheep. 4. Sites of carbohydrate and protein digestion as influenced by dietary reactive tannin concentration. Br. J. Nutr., 55: 123-137.

Cividini, A, D. Kompan, dan S. Žgur. 2007. The Effect Of Production System And Weaning On Lamb Carcass Traits And Meat Characteristics of Autochthous Jezerskosolcava Breed.Zootechnical Department, University of Ljubljana. Slovenia

Ferrier, G.R., L.P. Thatcher, and K.L. Cooper. 1995. The effect of lamb growth manipulation on carcass composition. CSIRO Meat Industry Ressearch Conference. 8A-18.

Lestari, C.M.S., E. Purbowati dan Mawarti 2001. Produksi edible portion karkas domba lokal jantan akibat penggantian protein konsentrat dengan protein ampas tahu. Jurnal Pengembangan Peternakan Tropis. Edisi Khusus : 228-235.

Priolo, A., Lanza, M., Biondi, L., Pappalardo, P., Young, O.A. (1998). Effect of partially replacing dietary barley with $20 \%$ Carob pulp on post-weaning growth, and carcass and meat characteristics of Comisana lambs. Meat Science, 50:355-363

Rahmadi. D. 2003. Pemberian Bungkil Inti Sawit dan Konsentrat yang Dilindungi Formaldehida untuk Meningkatkan Kandungan Asam Lemak Poli Tak Jenuh Daging Domba. Tesis. Sekolah Pascasarjana. IPB. Bogor.

Tranggono, B. Setiaji, Suhardi, Sudarmanto, Y. Marsono, A. Murdiati, I.S. Utami dan Suparmo, 1989. Petunjuk Laboratorium Biokimia Pangan. Pusat Antar Universitas Pangan dan Gizi. Universitas Gadjah Mada, Yogyakarta

Joseph.G. 2007. Suplementasi Sabun Kalsium dalam Pakan Ternak Ruminansia sebagai Sumber Energi Alternatif untuk Meningkatkan Produksi Daging yang Berkualitas. Disertasi. Sekolah Pascasarjana. IPB. Bogor. 